\title{
Pelatihan Seni Keterampilan Makrame Dan Penjualan Online Untuk Remaja Putri Di Panti Asuhan Darushsholihat
}

\author{
Wiwiek Mardawiyah Daryanto ${ }^{1 *}$, Amelia Naim Indrajaya ${ }^{2}$ \\ ${ }^{1,2}$ Sekolah Tinggi Manajemen Ipmi, Jakarta, Indonesia 12750 \\ Author E-mail: wiwiek.daryanto@ipmi.ac.id, amelia.naim@ipmi.ac.id
}

\begin{abstract}
A B S T R A K
Saat ini Indonesia masih sangat minim wirausahawan. Secara persentase, jumlah wirausaha di Indonesia baru sekitar 3\%. Angka tersebut masih jauh jika dibandingkan dengan negara tetangga di ASEAN seperti Malaysia, Singapura, dan Thailand yang sudah di atas 4\%. Kurangnya minat berwirausaha ini menjadi penyebab menambahnya tingkat pengangguran. Wadah untuk pengenalan wirausaha dan peningkatan kreatifitas pada anak-anak terlantar masih sangat sulit ditemukan di Indonesia. Panti asuhan merupakan salah satu tempat perkumpulan anak terlantar yang dapat digunakan untuk pengenalan akan wirausaha. Namun hal ini sering terlupakan karena keterbatasan dana dan keterbatasan tenaga pengasuh. Oleh karena itu, tujuan dari kegiatan pengabdian kepada masyarakat ini adalah untuk pengenalan terhadap pendidikan wirausaha untuk anak panti asuhan yang dimulai dari pembelajaran seni keterampilan yang unik seperti Makrame dan pengenalan terhadap cara berjualan tanpa atau rendah biaya melalui online. Seni Makrame adalah suatu kerajinan simpul-menyimpul dengan menggarap rangkaian benang/tali sehingga terbentuk aneka rumbai dan jumbai yang dapat dibuat menjadi ikat pinggang, penghias gerabah atau keramik, tas, hiasan dinding, keranjang untuk menggantung tanaman, dan sebagainya. Metode yang digunakan pertama memperkenalkan produk-produk kerajinan Makrame beserta manfaatnya, belajar membuat produk Makrame dengan mengajarkan cara membuat simpul-simpul, cara menjual produk secara langsung juga cara memasarkan secara online. Setelah kegiatan terlihat kemampuan anak anak panti asuhan dalam membuat produk produk Makrame. Disarankan agar perlu dilakukan pelatihan seni Makrame untuk produk lainnya yang lebih intensif secara berkala untuk meningkatkan skill mereka juga potensi kerjasama yang bisa dibangun misalnya anak-anak panti membentuk komunitas untuk menjual barang secara bersama.
\end{abstract}

Kata Kunci: Wirausaha, Panti Asuhan, Seni Ketrampilan Makrame, Pemasaran Online.

\section{A B S T R A C T}

Currently Indonesia still lacks of entrepreneurs. By percentage, the total entrepreneurship in Indonesia is around $3 \%$. This is far below compared to our neighbors in Asean like Malaysia, Singapore and Thailand which is above $4 \%$. The lack of interest of the entrepreneurship increases the jobless. In Indonesia, it is difficult to find a place / a facility for misfortune kids to learn about entrepreneurship or to develop the creativity. The orphanage will be one of the place for those kids to get the acknowledgment. But due to the limited funds and trainers, none is available. Therefore, the purpose of this community involvement activity was to introduce the entrepreneurship to the orphans by teaching them to learn to know about Makrame, the art of knotting cord or string in patterns to make 
decorative articles such as belt, ceramic articles, bags, wall decoration, plant hanger, etc. The methods which were used to introduce Makrame products with their usefulness, learning how to make knots, how to do direct selling of the product as well via online marketing. After the completion of the activity, the participants' ability making Makrame products has increased. It is suggested to continue giving the learning activity for various Makrame products, hence it will increase the participants' skills. As well the potential opportunity to build the network for marketing and selling the products.

\section{Keywords: Entrepreneur, Orphanage, Makrame art, Online marketing.}

Copyright (C) 2019 Authors. This is an open access article distributed under the Creative Commons Attribution License, which permits unrestricted use, distribution, and reproduction in any medium, provided the original work is properly cited.

\section{PENDAHULUAN}

Semakin pesatnya perkembangan jaman dan teknologi menciptakan begitu banyak peluang dan kesempatan baru yang dahulu belum ada dan sekarang menjadi ada. Kecepatan teknologi informasi mampu menembus batas-batas waktu dan menciptakan suatu daya saing baru yang merubah tatanan perekonomian dan usaha yang sudah terbentuk sekian lama oleh para pelaku usaha terdahulu. Agar mampu bersaing dalam era yang baru maka dibutuhkan daya saing yang unik dan inovatif. Untuk menumbuhkan daya saing yang unik dan inovatif dibutuhkan suatu kreatifitas yang dipicu dari keinginan untuk maju dan berkarya dan diimbangi oleh keterampilan dan daya seni yang memadai sehingga akan menghasilkan suatu value yang bisa diterima oleh orang banyak.

Untuk tujuan tersebut maka sangat penting arti dari penumbuhan kreatifitas melalui pembekalan dan pelatihan keterampilan Makrame yang diberikan kepada para remaja putri panti asuhan Darush Sholihat di kota Bogor, dimana dengan memiliki keterampilan tersebut maka para remaja putri tersebut mampu bersaing di era globalisasi saat ini dan menciptakan suatu peluang usaha baru dan memunculkan jiwa kewirausahaan agar kedepannya mampu menjadi salah satu penopang perekonomian nasional melalui keterampilan tersebut. Selain itu, diharapkan akan mampu memberikan peluang untuk meningkatkan taraf ekonomi mereka kedepannya.

Kerajinan Makrame berasal dari negara Arab yang asal muasalnya ditemukan pada tahun 850 M di era sebelum Kristus dengan bukti adanya relief sebagai dekorasi di negara Siria. Makrame berasal dari kata Arab yaitu "Mucharam" yang artinya susunan kisi-kisi, sedangkan kata "Macrame" berasal dari Turki yang mengambarkan rumbai-rumbai yang maknanya menyempurnakan pengerjaan lap/selubung wajah dengan simpul. Puncak kepopuleran Makrame di Arab terjadi di abad 13. Makrame disebarluaskan oleh para pedangan dari satu tempat ke tempat lain, khususnya oleh para pelaut. Para pelaut umumnya mengisi waktu senggang selama perjalanan berlayar yang lama dengan membuat simpul dari tali yang buah karyanya menjadi hadiah yang sangat disenangi keluarganya ketika sekembali mereka dirumah. Seni Makrame ini menjadi sangat popular dan digemari bahkan sampai ke benua Eropa dan bahkan saat itu ada penemuan Makrame di Amerika.

Berbagai jenis tenunan Makrame beserta simpulnya sangatlah indah dan memiliki daya tarik tersendiri. Dalam perkembangan jaman modern, Makrame juga cocok untuk mode baru dengan motif halus dan untuk penggunan hiasan eksklusif. Khusus untuk generasi muda, barangbarang yang bersifat dekoratif kini menjadi trend baru yang digemari dimana setiap orang dapat memilih mode sesuai keinginannya. Produk Makrame sebenarnya tergolong jenis kerajinan tangan klasik, tetapi pada jaman modern ini orang tidak begitu paham cara pemanfaatannya. Umumnya, selain membuat jaring/jala untuk berbelanja, tidak banyak ide yang bisa dipraktekan dengan simpul Makrame tersebut sehingga 
aplikasi Makrame lebih bersifat sebagai hiasan/pajangan yang bersifat mode baru. Dapat disimpulkan bahwa Makrame adalah salah satu bentuk kerajinan simpul-menyimpul dengan menggunakan bahan benang yang akhirnya menjadi suatu buah karya/hasil tenunan, melalui berbagai kombinasi simpul pada benang sehingga terbentuk aneka rumbai-rumbai.

Di Indonesia sendiri, kerajinan Makrame sudah cukup dikenal, dan memiliki pangsa pasarnya sendiri. Di dalam dunia fashion, teknik simpul Makrame sempat hit di tahun 60-70an dan muncul lagi di tahun 2011 dalam beberapa fashion dari para designer terkenal (Waridah Muthi'ah, 2013). Pasar offline Makrame di Indonesia bisa ditemukan di beberapa tempat, misalnya di Bali yang tersebar di berbagai tempat seperti Kuta, Ubud, dan lainnya.

Perkembangan ponsel dalam dua dekade terakhir sangat mempengaruhi perilaku konsumen, dimana fungsi ponsel bukan lagi telepon dan SMS, namun bisa dijadikan mini laptop dimana kegiatan bekerja dan berbisnis bisa dilakukan melalui benda kecil tersebut. Berbisnis yang memanfaatkan teknologi baik melalui ponsel atau tools lainnya yang sering disebut sebagai e-bisnis atau lebih dikenal dengan e-commerce. Disamping itu, pertumbuhan orang yang menggunakan teknologi internet yang semakin besar dan tumbuh signifikan disupport oleh teknologi ponsel dan aplikasi, telah mengubah pola transaksi orang. Dimana pada tahun 1998 hanya ada 500ribu orang pakai internet dan tahun 2017 diestimasi sudah 143 juta orang (Waridah Muthi'ah (2013).

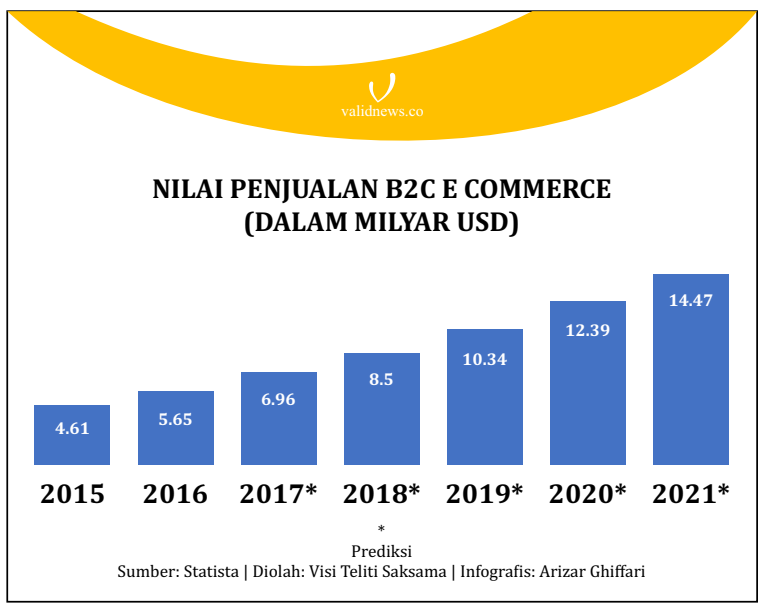

Sumber: Statista (2016)

Gambar 2. Nilai Transaksi dalam E-Commerce Indoensia

Tentunya pertumbuhan pengguna internet memunculkan potensi bisnis dimana orang mulai bertransaksi dengan internet, hal tersebut bisa dilihat dalam pertumbuhan transaksi menggunakan media e-commerce, dimana ditahun 2015 hanya US\$ 4,6 Milyar dan diprediksi

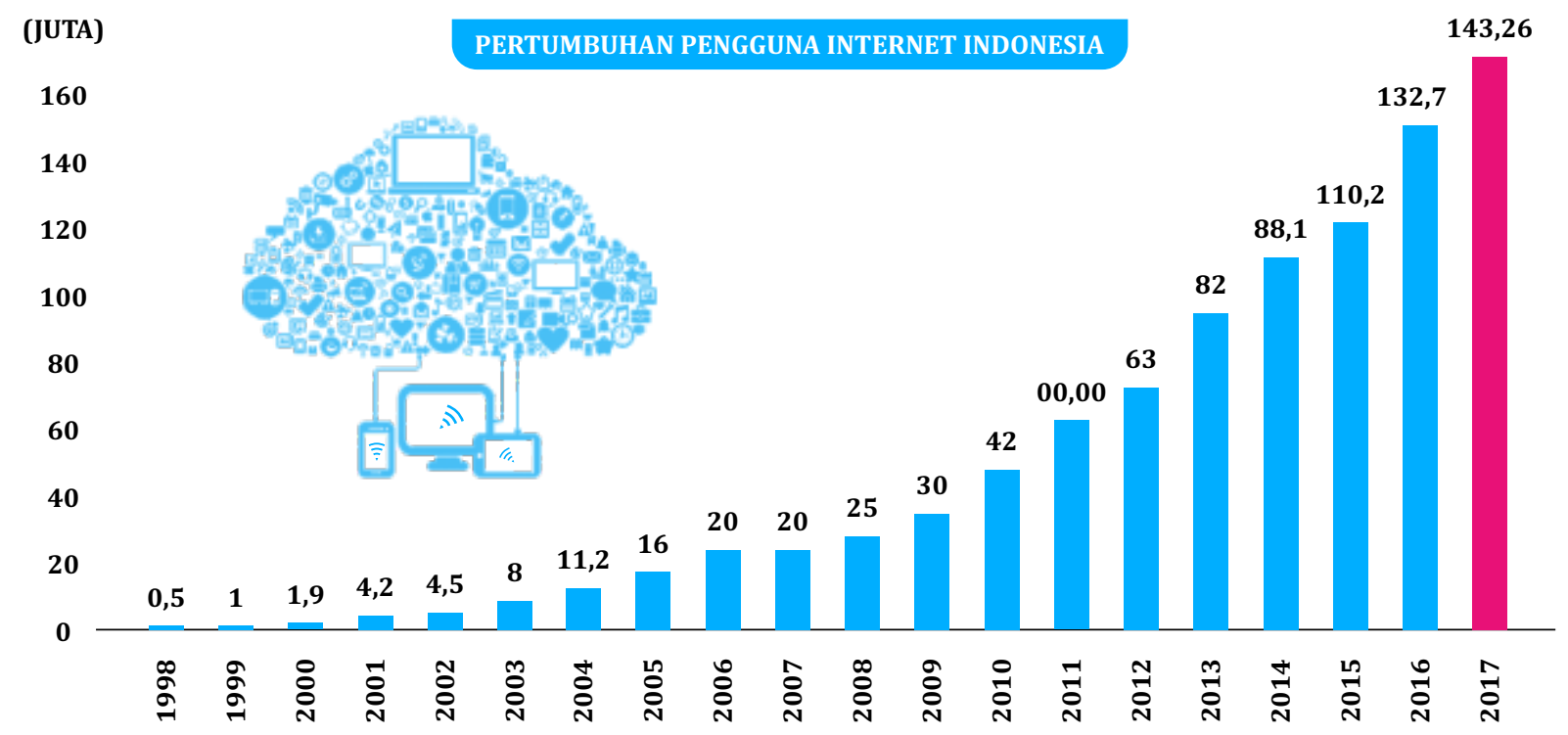


akan seniau US\$14,5 Milyar pada tahun 2021 atau 6 tahun dari 2015 (Sita Wardhani SE, MSc, 12 Sept 2017). Nilai transkasi itu terus terdorong dengan makin beragamnya jenis barang yang diperdagangkan dan model trasaksi yang terus berinovasi. Kemudian, bila kita melakukan pencarian kata "\#jualmacrame" di Instagram akan diperoleh paling tidak 5000 public posting yang cukup menunjukkan pasar Makrame di Indonesia cukup besar. Pasar online Makrame di Indonesia sangat besar walaupun sulit untuk dikuantifikasi secara persis berapa besarnya.

Menjadi pengrajin Makrame juga relatif memiliki risiko finansial yang rendah, karena bila dikerjakan oleh kita sendiri maka modal untuk membuat seuatu karya Makrame praktis hanyalah Tali / Benang katun yang harganya hanya sekitar Rp 9.000 per gulung. Sedangkan untuk membuat sebuah plant hanger hanya membutuhkan modal 1 gulung benang, sedangkan untuk membuat tas Makrame membutuhkan sekitar 2-3 gulung. Bila tidak laku maka kerugian hanyalah sejumlah harga benang tersebut ditambah waktu yang terpakai bebrapa jam untuk mebuat sebuah karya. Sedangkan bila terjual maka margin yang didapat per karya bisa puluhan sampai ratusan ribu rupiah.

Dibawah ini adalah finansial model untuk bisnis Makrame dengan asumsi produk plant hanger, dikerjakan sendiri dan dijual secara online:

Beberapa kisah sukses pengrajin Makrame bisa dilihat pada cerita dibawah ini :

1. Niky Sugesti, pemilik bisnis Etalase Catchy yang juga merupakan mentor yang bersedia membantu project ini memiliki fokus pada Makrame hiasan dinding, plant hanger, tirai dan sebagainya. Lapaknya ada di IG maupun facebook serta juga memiliki website yang memajang karyanya (Niky Sugesti (2016).

2. Ayu Pandansari (27 tahun) memperoleh omzet 3-4 juta per bulan dengan berjualan brand Haka Collection di instagram dan facebook fokus pada produk tas Makrame (Bisnis UKM 2018).

3. Joko membuat aneka kerajinan, dari meja gantung, akuarium gantung, gantungan pot, tirai, sampai tempat tidur gantung dari Makrame Harga produk mulai termurah Rp.5000 sampai yang paling mahal Rp.2,5 juta untuk meja gantung. Semakin mahal maka pengerjaan dan detail semakin sulit. Pelanggan tetap dari luar negeri, adalah negara- negara pecinta produk handmade, seperti Swiss, Jepang, Belanda, Jerman (Biografi Pengusaha Wirausaha Mandiri, 2016).

4. Nadia Maya Ardiani, salah seorang pegiat Makrame di Surabaya yang membuka bisnis Makrame melalui brand Kembang api Macramé \& Some ini. Untuk menghasilkan sebuah karya Makrame berukuran 1 meter, dibutuhkan waktu 2 hingga 3 hari. Makin kecil dan mudah, makin sedikit waktu yang dibutuhkan. Sedangkan untuk harga, juga bervariasi. Mulai dari ratusan ribu sampai jutaan rupiah (Majalah SCG Edisi April 2018).

5. Ibu Lukitri Ernarayani membuat tas macrame yang dipasarkan dengan harga 250ribu sampai 400 ribu denagn cara online maupun galerinya di Boyolali (Desa Mojolegi Web 14 Sept 2017).

Tujuan pengabdian masyarakat ini adalah pengembangan kreatifitas remaja putri panti asuhan dengan memberikan pengajaran seni Makrame khususnya gantungan tanaman, membangun kesadaran berwirausaha, serta pengenalan usaha melalui pemasaran online. Pada pelatihan ini, target utama nya adalah melatih para remaja putri tersebut untuk mengenal dan mamahami dasar-dasar dari pembuatan Makrame. Teknik Makrame yang diajarkan lebih memfokuskan pada cara membuat gantungan pot tanaman. Selain itu pembekalan tentang cara memasarkan hasil karya mereka secara onlined an offline juga menjadi focus penting dalam pelatihan tersebut sehingga para remaja putri tersebut mendapat pengetahuan tentang bagaimana cara menjual dan memasarkan hasil karyanya.

Memberikan pembekalan keterampilan dan berwirausaha tentang konsep, model, aplikasi seni Makrame dan pemasaran online sehingga peserta dapat mulai berpikir untuk wirausaha secara 
kreatif dan mendapatatkan pendapatan secara berkesinambungan untuk melanjutkan kehidupan yang lebih baik. Manfaat dari program pembekalan ini khususnya menambah wawasan anak Yatim Paiatu di Panti Asuhan Darush Sholihat, tentang aplikasi membuat kerajinan Makrame dimulai dari sebuah plant hanger dan konsep usaha mandiri, mulai dari pemasaran melalui online (facebook, instagram), membuka lapak di e-commerce, supply chain sederhana, menghitung harga jual, sampai cara melakukan transaksi secara online, mengirimkan barang jualan, dan mampu menciptakan daya saing kedepannya.

Materi yang diberikan meliputi: konsep membuat seni Makrame (berupa lembaran cara menyimpul tali), bahan-bahan yang diperlukan untuk membuat gantungan tanaman seperti tali katun, gantungan S, alat ukur atau meteran, besi bulat, pot, gunting, yang disiapkan dalam satu tas, dan materi konsep, aplikasi dan strategi pemasaran online.

Tabel 1. Finansial Model untuk Bisnis Makrame

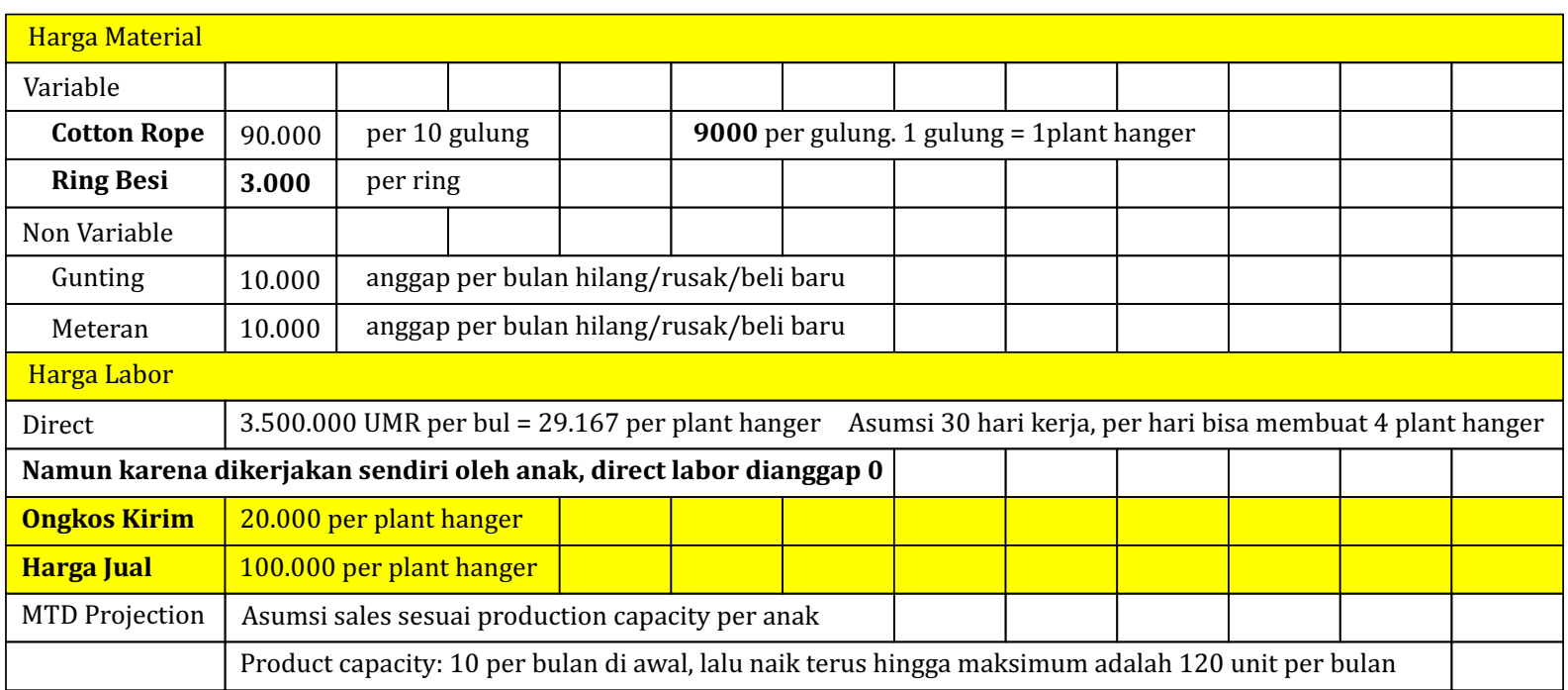

\begin{tabular}{|c|c|c|c|c|c|c|c|c|c|c|c|c|}
\hline & Bulan 1 & Bulan 2 & Bulan 3 & Bulan 4 & Bulan 5 & Bulan 6 & Bulan 7 & Bulan 8 & Bulan 9 & Bulan 10 & Bulan 11 & Bulan 12 \\
\hline Sales Unit & 10 & 20 & 30 & 40 & 50 & 60 & 70 & 80 & 90 & 100 & 110 & 120 \\
\hline Sales & 1.000 .000 & 2.000 .000 & 3.000 .000 & 4.000 .000 & 5.000 .000 & 6.000 .000 & 7.000 .000 & 8.000 .000 & 9.000 .000 & 10.000 .000 & 11.000 .000 & 12.000 .000 \\
\hline \multicolumn{13}{|l|}{ Var Cost } \\
\hline Direct material & 120.000 & 240.000 & 360.000 & 480.000 & 600.000 & 720.000 & 840.000 & 960.000 & 1.080 .000 & 1.200 .000 & 1.320 .000 & 1.440 .000 \\
\hline Direct labor & - & - & & - & - & - & - & - & - & - & - & - \\
\hline Shipping cost & 200.000 & 400.000 & 600.000 & 800.000 & 1.000 .000 & 1.200 .000 & 1.400 .000 & 1.600 .000 & 1.800 .000 & 2.000 .000 & 2.200 .000 & 2.400 .000 \\
\hline Total Var & 320.000 & 640.000 & 960.000 & 1.280 .000 & 1.600 .000 & 1.920 .000 & 2.240 .000 & 2.560 .000 & 2.880 .000 & 3.200 .000 & 3.520 .000 & 3.840 .000 \\
\hline Contribution Margin & 680.000 & 1.360 .000 & 2.040 .000 & 2.040 .000 & 3.400 .000 & 4.080 .000 & 4.760 .000 & 5.440 .000 & 6.120 .000 & 6.800 .000 & 7.480 .000 & 8.160 .000 \\
\hline Fixed cost & 20.000 & 20.000 & 20.000 & 20.000 & 20.000 & 20.000 & 20.000 & 20.000 & 20.000 & 20.000 & 20.000 & 20.000 \\
\hline Fixed man $\mathrm{OH}$ & - & - & & - & - & - & - & - & - & - & - & - \\
\hline Fixed sga ad & - & - & & - & - & - & - & - & - & - & - & - \\
\hline Total Fixed & 20.000 & 20.000 & 20.000 & 20.000 & 20.000 & 20.000 & 20.000 & 20.000 & 20.000 & 20.000 & 20.000 & 20.000 \\
\hline Op income & 660.000 & 1.340 .000 & 2.020 .000 & 2.020 .000 & 3.380 .000 & 4.060 .000 & 4.740 .000 & 5.420 .000 & 6.100 .000 & 6.780 .000 & 7.460 .000 & 8.140 .000 \\
\hline \multicolumn{2}{|c|}{ Harga Break even adalah } & \multicolumn{5}{|c|}{36.000 per plant hanger include ongkir } & & & & & & \\
\hline \multicolumn{2}{|c|}{ Harga Break even adalah } & \multicolumn{5}{|c|}{16.000 per plant hanger exclude ongkir } & & & & & & \\
\hline
\end{tabular}


Peserta yang mengikuti ilmu pembekalan Makrame dan strategi pemasaran online adalah remaja putri Panti Asuhan Darush Sholihat di Bogor, Jawa Barat dan juga beberapa orang yang turut berpartisipasi secara sukarela dan ikut mendanai acara. Profil anak-anak panti ini adalah pelajar wanita SLTA dengan umur 15-18 tahun.

\section{METODE PELAKSANAAN}

Di era globalisasi ini, masalah lapangan pekerjaan masih sangat dominan khususnya bagi lulusan pendidikan formal (SMA, D3 maupun S1) dimana daya serap industri yang tidak seimbang dengan jumlah lulusan. Oleh sebab itu, upaya pemerintah dalam menggalakan program kewirausahaan terus ditingkatkan baik dari industry berbasis produk, kerajinan maupun industri non-produk (layanan dan teknologi).

Gerakan program kewirausahaan yang akhirakhir ini giat digalakan oleh pemerintah guna menumbuhkan wirausahawan, mengurangi pengangguran dan lebih meningkatkan daya saing ekspor khususnya dalam berupa produkproduk kerajinan berupa Makrame, maka kami melakukan kontribusi membantu program pemerintah ini sekaligus memberikan nilai tambah terkait tanggung-jawab atas pengembangan komunitas sosial di panti asuhan yang kami yakin dapat bisa memberikan nilai tambah pada anakanak panti bagi masa depan masing-masing.

Kegiatan pengabdian kepada masyarakat (Abdimas) ini dilaksanakan oleh para mahasiswa eksekutif (EMBA), perwakilan fakultas dan Sekolah Tinggi Manajemen IPMI pada tanggal 29 April 2018 di Panti Asuhan Darush Sholihat Bogor, Jawa Barat. Kegiatan ini diadakan agar anak-anak panti asuhan mengembangkan keterampilan membuat kerajinan produk Makrame, nilai tambah secara ekonomis bagi anak-anak serta menjadi batu loncatan awal mengembangkan jiwa wirausaha mereka dari keahlian yang dimiliki.

Metode kegiatan pengembangan komunitas sosial yang kami terapkan sebagai berikut:

1. Para anak-anak panti asuhan kami perkenalkan tentang produk-produk kerajinan Makrame beserta manfaatnya.

2. Para anak-anak panti asuhan kami perkenalkan seni membuat Makrame yang mudah diterapkan kesehariannya.

3. Buah karya produk Makrame di kegiatan awal, kami membantu mempromosikan saat kegiatan eksebisi di lingkungan kampus.

4. Setelah bisa membuat produk Makrame dan untuk manfaat berkesinambungan, anak-anak panti kami berikan pengetahuan cara menjual / memasarkan buah karya produk Makrame masing-masing melalui penjualan online atau sosial media.

Garis-besar dari pelaksanaan kegiatan sosial ini mencakup sebagai berikut: penyusuan ide kegiatan sosial sesuai arahan dosen, pemilihan sasaran / tujuan aktifitas sosial ini, penentuan waktu, tempat dan lokasi, persiapan kegiatan, sesi pengenalan awal produk-produk kerajinan Makrame (motif dan jenis bahan), sesi bimbingan cara membuat produk Makrame, sesi bimbingan bagaimana cara menjual Makrame secara on-line (via social media), mempromosikan hasil buah karya Makrame dan akhirnya penyusunan laporan hasil kegiatan.

\section{HASIL DAN PEMBAHASAN}

Adapun hasil kegiatan yang telah dilaksanakan sesuai dengan rancangan atau rencana kegiatan adalah sebagai berikut:

a) Meningkatnya pengetahuan remaja putri mengenai diversifikasi produk Makrame. Pada kegiatan ini, peserta remaja putri dikenalkan produk-produk kerajinan Makrame beserta manfaatnya. Perhiasan Makrame terkenal di kaum neo hippie Amerika dan kelompok grunge mulai pada awal tahun 70-an yang sangat dominan menggunakan simpul persegi dan simpul granny. Beberapa contoh produk Makrame antara lain sebagai berikut (Nanang Ajim (2015):

b) Meningkatnya keterampilan remaja putri dalam mendesain dan membuat berbagai macam bentuk produk Makrame.

Dalam kegiatan ini, fasilitator mengajarkan kepada 
remaja putri tentang macam-macam Ikatan Simpul untuk seterusnya dibuat berbagai produk produk Makrame seperti tersebut diatas. Bahan utama dalam pembuatan Makrame ini adalah tali kur dan alat yang dibutuhkan adalah gunting. Pertama para remaja putri diajarkan untuk membuat Ikatan Simpul Kepala yang terdiri dari dua jenis simpul yaitu Larks Head Knot (LHK) dan Vertical Larks Head Knot. Setelah mereka dapat membuat simpul2 tersebut diteruskan dengan ikatan simpul kedua yaitu Ikatan Simpul Rantai atau Ikatan Simpul Half Knot (HK) dan berikutnya Ikatan Simpul Ganda atau Ikatan Simpul Square Knot (SK) dan terakhir adalah Ikatan Simpul Anyam yang juga terdiri dari dua jenis simpul yaitu Half Knot Sinnet (HK Sinnet) dan Square Knot Sinnet (SK Sinnet). Lihat gambar dibawah untuk langkah langkah pembuatan dari ke enam simpul tersebut.

Tabel 2. Bentuk dan Fungsi Makrame, Ikatan Simpul dan Hiasan Penunjang

\begin{tabular}{|c|c|c|c|}
\hline Bentuk Makrame & Fungsi Makrame & Ikatan Simpul yang Digunakan & Hiasan Penunjang pada Makrame \\
\hline Tas pinggang & Fungsi pakai & Simpul kepala, dan simpul ganda & Gantungan tas, kancing, resleting \\
\hline Gantungan kunci & Fungsi hias & Simpul rantai & Ring besi \\
\hline Gelang & Fungsi hias & Simpul anyam & Manik-manik \\
\hline Tas & Simpul & Simpul anyam & Gantungan tas, kancing, resleting \\
\hline
\end{tabular}

Simpul Kepala

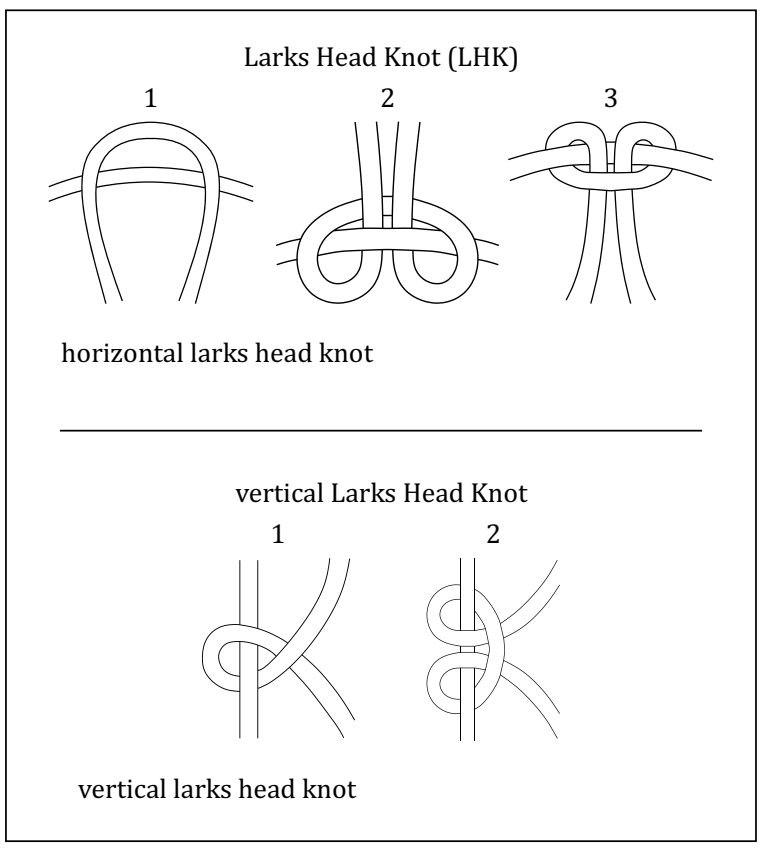

Simpul Rantai

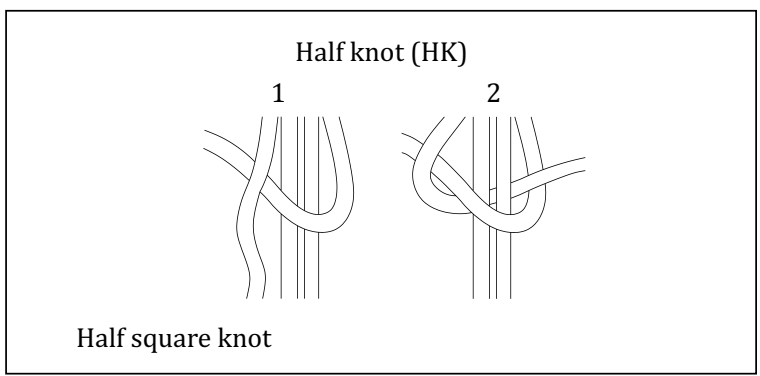

Simpul Anyam

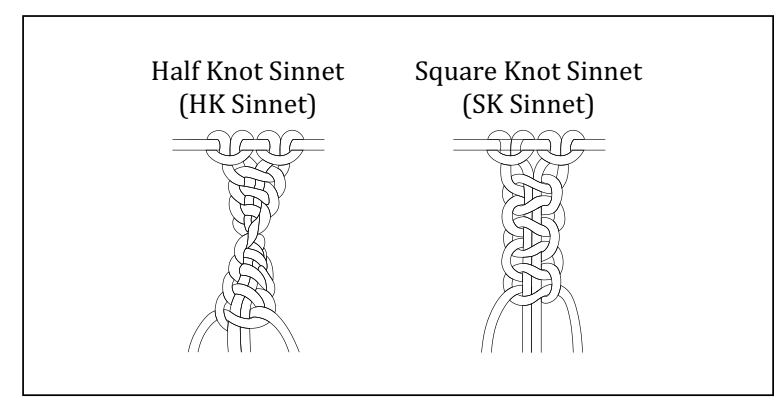

Simpul Ganda

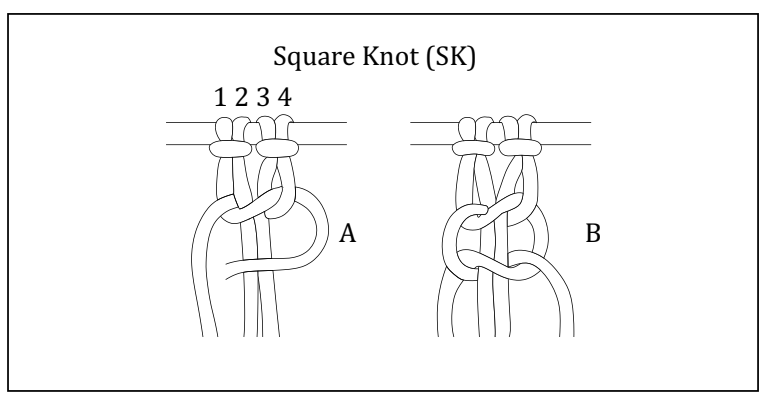

Gambar 3. Jenis Jenis Ikatan Simpul Kepala,

Ikatan Simpul Rantai, Ikatan Simpul Ganda dan Ikatan Simpul Anyam 


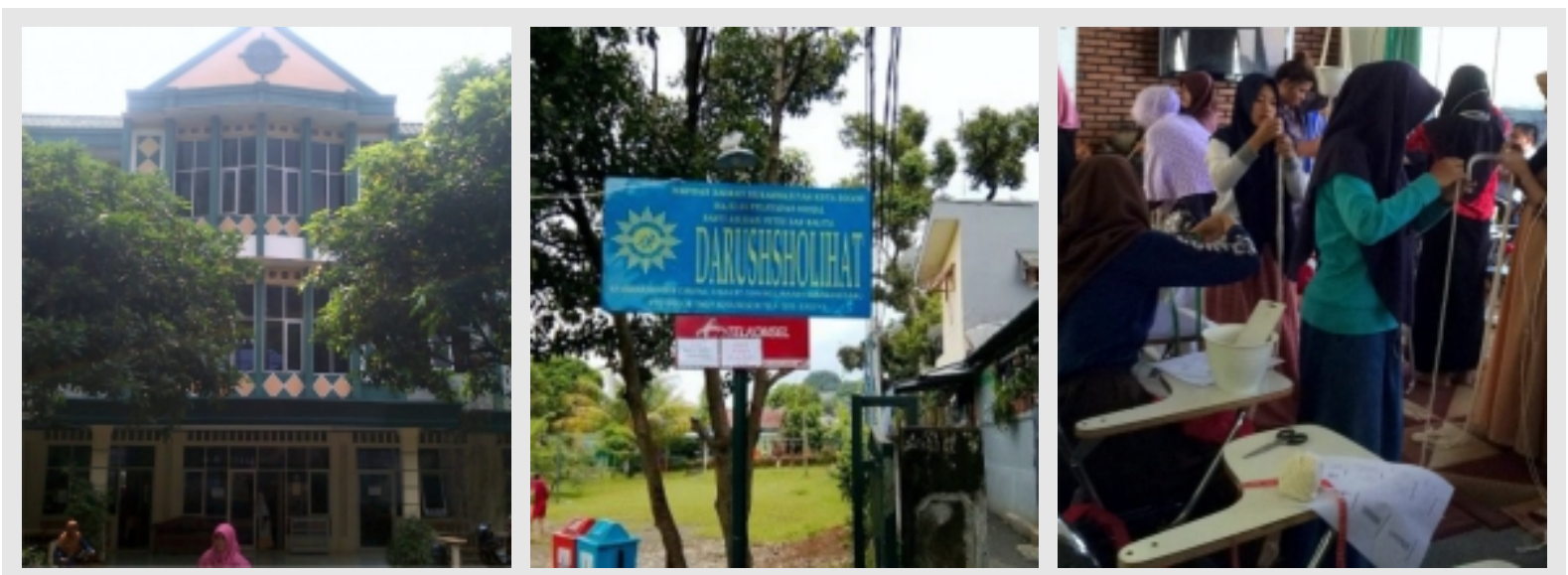

Gambar 4. Foto Kegiatan Pelatihan Remaja Putri di Panti Asuhan Darushsholihat, 29 April 2018

c) Diversifikasi produk Makrame yang telah didesain atau dibuat, kemudian dijual secara offine dalam kegiatan Exhibition di Kampus Sekolah Tinggi Manajemen IPMI.

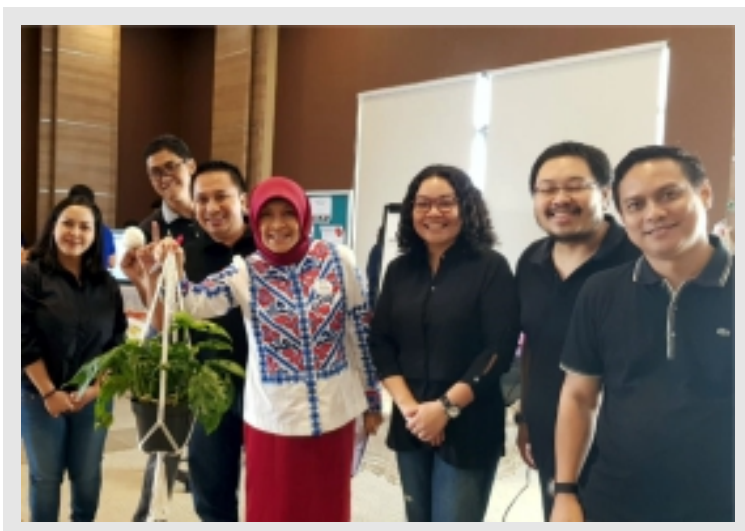

Gambar 5. Foto Kegiatan Penjualan Offline Produk Makrame Hasil Karya Remaja Putri Pada Pameran Hasil Kegiatan ABDIMAS di Sekolah Tinggi Manajemen IPMI, 12 Mei 2018

d) Meningkatnya kemampuan remaja putri dalam memasarkan diversifikasi produk Makrame secara online.

Selanjutnya produk Makrame yang sudah didesain dan dibuat dengan berbagai macam jenis dipasarkan secara online. Produk Makrame sebagai saah satu item barang yang menarik dan cantik, memiliki daya Tarik tersendiri untuk terus berkembang melalui e-commerce. Hal ini tentunya membuat pengrajin Makrame tidak boleh kehilangan potensi ini. Keunggulan produk didukung oleh model yang cantik dan kualitas barang yang sangat baik menjadi salah satu kunci kepercayaan konsumen e-commerce untuk membeli Makrame. Berikut adalah beberapa jenis karya Makrame yang sudah masuk pasar e-commerce:
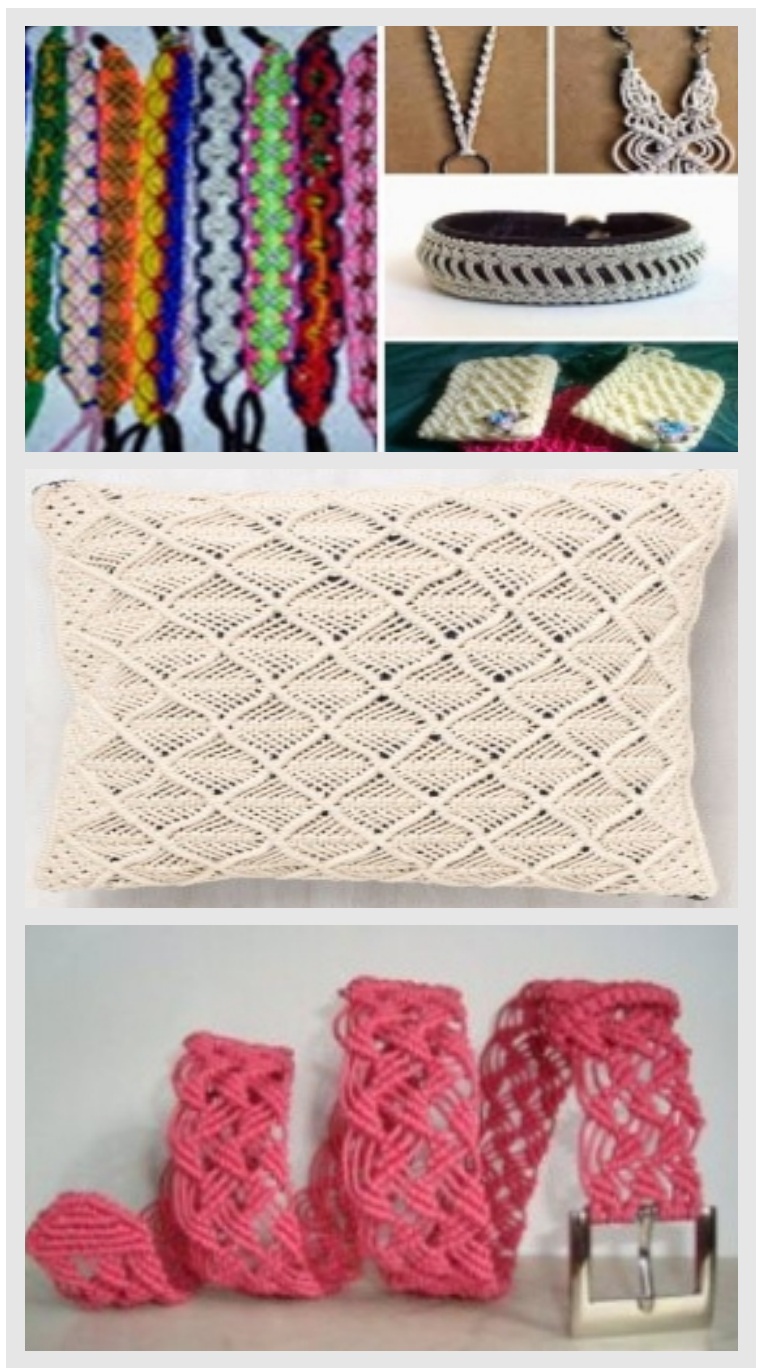


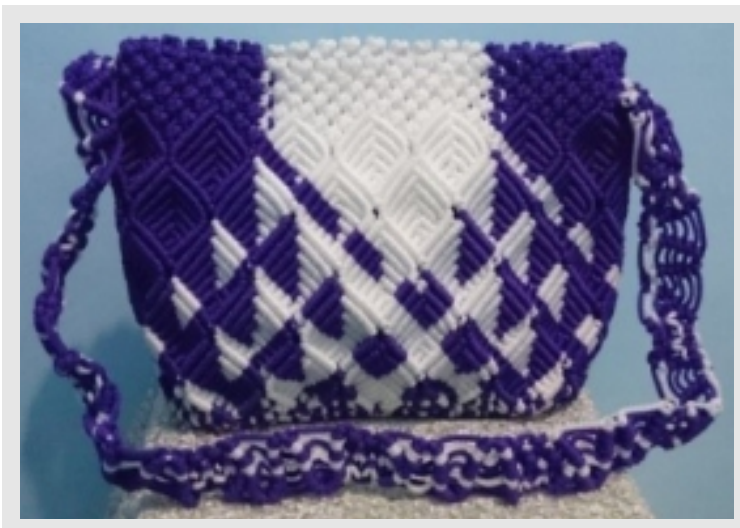

Gambar 6. Berbagai macam model produk Makrame

\section{KESIMPULAN DAN SARAN}

Dari uraian ringkasan tersebut dapat disimpulkan bahwa remaja putri dan pengurus Panti Asuhan Darush Sholihat merasa beruntung atas kedatangan mahasiswa Sekolah Tinggi Manajemen IPMI dengan memberikan ilmu seni Makrame yang unik dan kreatif serta pelajaran cara berjualan online. Pasca pelatihan, kelompok mepresentasikan hasil pembuatan macramé plant hanger anak anak panti asukan di Kegiatan Pengabdian Masyarakat IPMI tanggal 12 May 2018 yang dihadiri sekitar 100 orang dan berhasil menjual sekitar 35 hasil karya aanak panti dengan harga @Rp100.000,- dan hasil penjualan tersebut diberikan langsung ke pengurus panti untuk remaja putri dan membeli bahan-bahan yang diperlukan untuk dapat melanjutkan seni Makrame. Kegiatan ini telah membantu mereka menyadari betapa mudahnya dan menyenangkan untuk memulai usaha sejak dini.

Oleh karena itu, disarankan agar perlu dilakukan pelatihan seni Makrame untuk produk lainnya yang lebih intensif secara berkala untuk meningkatkan skill mereka. Proyek ini hanyalah pembuka awal supaya anak anak panti memiliki skill dasar membuat Makrame dan mengetahui aspek bisnis untuk menghasilkan uang dari kerajinan tersebut. Untuk kedepannya anakanak panti ini apabila ingin maju terus harus terus mendalami teknik teknik Makrame yang lebih tinggi, bisa dengan cara otodidak dari tutorial online di youtube, atau bisa juga dengan cara berkomunikasi dengan mentor awal yang kami bawa pada proyek ini yaitu Ibu Niky.

Selain berbisnis sendiri / swadaya, berbagai potensi kerjasama bisa juga dibangun misalnya anak-anak panti membentuk komunitas untuk menjual barang secara bersama. Atau anak-anak panti bekerja sama dengan pengusaha Makrame yanng sudah maju seperti Ibu Niky untuk menjadi pengrajin yang mengerjakan outsource pesanan, ataupun melakukan bisnis secara konsinyasi. Kami berharap berangkat dari proyek ini kedepannya akan muncul kisah-kisah inspiratif dari anak-anak panti yang membantu mereka unntuk menghasilkan uang / berbisnis yang sustainable sambil mereka tetap menyelesaikan pendidikannya.

\section{DAFTAR PUSTAKA}

Business UKM. (2018). Inspirasi Bisnis. Di akses online dari https://bisnisukm.com/modal-rp-25-ribu-iburt-ini-bisnis-kerajinan-beromzet-jutaan-rupiah.html

Biografi Pengusaha Wirausaha Mandiri. (2016). Buka Usaha Tali Temali Untung Kalau Digali. Di akses dari https://biografi-pengusaha.blogspot.com/2016/09/jualan-simpul-pramuka.html

Desa Mojolegi. (2017). Pengrajin Tas Makrame, Di akses dari http://mojolegi.sideka.id/2017/09/14/ pengrajin-tas-macrame/

Majalah SCG. (2018). Di akses online dari https://edoc.site/majalah-scg-edisi-april-2018-pdf-free.html

Nanang Ajim. (2015). Produk Kerajinan Tehnik Makrame. Di akses online dari http://www.mikirbae.com/ 2015/12/produk-kerajinan-fungsi-pakai.html 
Niky Sugesti. (2016). Etalase Catchy 2016 - 2017. Di akses online dari www.etalasecatchy.com Wardhani, S. (2017). Perkembangan E-commerce di Indonesia. Di akses online dari http://www.validnews.co/Perkembangan-E-commerce-di-Indonesia--1--YXAij

Waridah Muthi'ah. (2013). Teknik Makrame dalam Tren Fashion: Ironi Terhadap Prinsip Dromologi (Studi Kasus Koleksi Spring/ Summer Dior 2011), Serat Rupa Vol. 1 Edisi I April 2013, dari http://majour.maranatha.edu/index.php/sr/article/download/1241/1306 